\title{
RELEVANCE OF THE FATWA OF THE INDONESIAN ULEMA COUNCIL TO THE RENEWAL OF ISLAMIC FAMILY LAW IN INDONESIA (STUDY OF MUI FATWA NUMBER: 4/MUNAS VII/MUI/8/2005 ON MARRIAGE OF DIFFERENT RELIGIONS)
}

\author{
Puad Muzakkar Siregar \\ Kantor Wilayah Kementerian Agama Propinsi Bengkulu \\ JI. Jl. Jenderal Basuki Rahmat No. 10, Kota Bengkulu 38221 \\ Email: puad.muzakkar@gmail.com
}

\begin{abstract}
Fatwa is a practical law similar to fiqh (al-ahkâm al-'amaliyah). Therefore, the fatwa must be context-bound; context of time (tempus), place (locus), context of natural conditions, social context, demographic context, and other contexts. In the Indonesian context, the Indonesian Ulema Council (MUI) is the official state-recognized institution to issue fatwas as guidelines for Indonesian Muslims. This paper answers two questions: how is the MUI fatwa related to the legal status of interfaith marriages? Furthermore, is the MUI fatwa on interfaith marriage relevant to the reform of Islamic family law in Indonesia? As a result, although many scholars allow interfaith marriages because Muslim men and women are experts of the book, the MUI fatwa forbids interfaith marriages based on sadd al-dzari'ah to prevent negative impacts. This is a family law product with a renewal side, because it is responsive to social dynamics and changing times, by prioritizing the benefit based on maqasid shari'ah.
\end{abstract}

Keywords: Fatwa; Family Law Reform; Interfaith Marriage

\begin{abstract}
Abstrak: Fatwa merupakan hukum praktis sama dengan fiqih (al-ahkâm al-amaliyah). Karena itu fatwa pasti sangat terikat dengan konteks; konteks waktu (tempus), konteks tempat (locus), konteks kedaaan alam, konteks social, konteks demografi, dan konteks-konteks lainnya. Dalam konteks Indonesia, Majelis Ulama Indonesia (MUI) adalah lembaga resmi yang diakui negara untuk mengeluarkan fatwa sebagai pedoman bagi Muslim Indonesia. Tulisan ini menjawab dua pertanyaan yaitu bagaimana fatwa MUI terkait status hukum perkawinan beda agama? Dan apakah fatwa MUI tentang perkawinan beda agama relevan dengan pembaruan hukum keluarga Islam di Indonesia?. Hasilnya, walaupun banyak ulama yang membolehkan perkawinan beda agama dengan syarat muslim laki-laki dengan wanita ahli kitab, tapi fatwa MUI mengharamkan perkawinan beda agama berdasarkan sadd al-dzari ah untuk preventif terhadap dampak negatif yang ditimbulkan. Ini merupakan produk hukum keluarga yang memiliki sisi pembaruan, karena responsif terhadap dinamika sosial dan perubahan zaman, dengan memprioritaskan kemashlahatan berdasarkan maqasid syari ah.
\end{abstract}

Kata kunci: Fatwa; Pembaruan Hukum Keluarga; Perkawinan Beda Agama 


\section{Introduction}

The Qur'ân and the Sunna are the primary sources of Islamic Shari'ah, impossible to understand by all Muslims except those who study deeply about the field of religious science. That is why the scholars took on the role. Its role is significant in realizing religious guidance to provide a clear and correct understanding through fatwas. ${ }^{1}$

Fatwa is one of the products of Islamic legal thought that has existed since the Prophet Muhammad (peace be upon him), along with fiqh, tafsir and jurisprudence. Fatwa is a practical law of fiqh (al-ahkâm al-'amalîyah). Therefore, fatwa must be very attached to the context of time (tempus), place (locus), the regional context of nature, social context, demographic context, and other contexts. So it is not surprising that there is an Indonesian version of the legal fatwa, the Malaysian version of the legal fatwa, and others following the context and situation of each Muslim country. Based on this time, there has been a fatwa since the time of the prophet Muhammad ( peace be upon him), the time of companions, the time of tabi' in to contemporary times, following the context of each age. The combination of the context of the place and the context of this era makes fatwas born with various patterns.

In the Qur'ân, Allah (swt) tells those who do not understand a problem to ask experts in their field, in terms of religion of course the experts are scholars, it is explained in the word of Allah Swt surah Al-Nahl [16] verse 43 which reads:

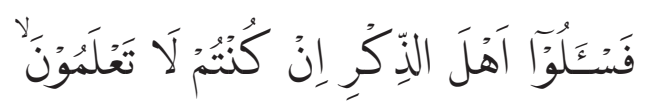
"..Ask those who know if you do not know" (QS. Al-Nahl [16] : 43)

1 Ma'ruf Amin, Fatwa dan Kedudukannya Dalam Islam, Paper, presented at the International Conference on Fatwa at Jakarta, Tuesday 25 December 2012.
MUI through its fatwa has sought to reform Islamic law. The renewal of Islamic law is an attempt to make Islamic law appear fresher and look modern (not outdated) and answer the problems that arise in a dynamic society. In the issue of marriage of different religions, scholars have various opinions regarding their legal status. In the Indonesian context, what is the MUI fatwa on this issue? Furthermore, is the MUI fatwa on marriage of different religions relevant to the renewal of Islamic family law in Indonesia?

\section{Fatwa}

The Indonesian Ulema Council (MUI) as a forum for the consultation of Muslim scholars, leaders and scholars, has a noble role as a protector for Indonesian Muslims, especially in solving and answering all socioreligious and national problems that arise amid society. The answer given by MUI is in the form of a fatwa. ${ }^{2}$

The word fatwa (فتوى) etymologically, comes from arabic which means the answer to something that is musykil in the field of shari'ah law and legislation. ${ }^{3}$ Ibn Manzhûr (d. $711 \mathrm{H})$ said: the word fatwa means تبيين "explain complicated laws”. The word fatwa فتوى ) can also mean question. This is following the word of Allah SWT in QS. Al-Shoffat (37) verse 11 as follows:

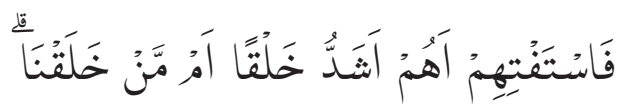

"So ask them, "Are they the stronger, or what we have created?" (QS. Al-Shoffat (37): 11)

2 Iffatul Umniati Ismail, Telaah Kritis Metodologi Istinbath MUI (Studi Kasus Fatwa Tentang Golput), in: Media Syari'ah, Vol. XIII No 1 Januari-Juni 2011, p. 73

${ }^{3}$ Sa'di Abu Jaib, Qamus al-Fiqhi Lughotan wa Istilahan, ( Damascus: Dar al-Fikr, 1988), h. 281. See. Ibrahim Mushtofa dkk, Mujjam al-Wasith, ( t.t: Dar al-Da'wah, t.th), Jilid 2, h. 673. See. Ali bin Muhammad Abu Hasan al-Jurjani, Al-Tárifât, (Bairut: Dar al-Kutub al-iilmiyah, t.th), p. 32 
Furthermore, in Al-Munjid it is mentioned that fatwa(فتوى) the plural fatâwa (فتتوى) means the name of what a religious expert describes law. ${ }^{4}$ In various forms of derivation, the word often used is aftâ (أفنَى) yuftî (يُقَتِنَ) which means berfatwa, yastaftî and istaftî ( يستفتي - استفتي)

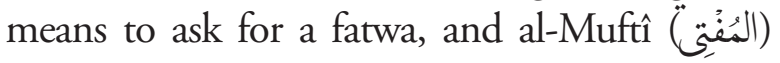
which means fatwa giver. ${ }^{5}$

According to Al-Fayumi, al-fatwa (الفتوَى) feels from the word al-fata (الفنَ) meaning robust youth. It is meant by a vigorous youth, that a mufti of fatwas must be strong in the face of questions posed by a person or group with refreshing answers and strong arguments. ${ }^{6}$

While in terminology, fatwa is explaining the religious law of a problem as an answer to the question posed by the fatwa requester (mustaftî), both individual and collective, both known and unknown. ${ }^{7}$ According to Zamaskhsyari (w.538 H), al-fatwa is the Shari'a law's explanation of a problem on the question of a person or group. ${ }^{8}$ In the great dictionary, Indonesian interprets "fatwa" as the "answer" (decision, opinion) given by the mufti on a problem." In addition, fatwa also means "the advice of religious believers; Good lessons or advice.?

${ }^{4}$ Louis Ma'luf, Al-Munjid fi al-lughah wa al-'alâm, (Beirut: Dar al-Masyriq, 1976), Jilid. I, p. 529.

5 Atabik Ali, dan Zuhdi Muhdlor, Qamus Al-Ashri, Arabi Indunesi, ( Krapyak: Multi Karya Gratifika, 2003), h, 170. See. Ahmad Warson Munawwir, Kamus alMunawwir Arab Indonesia Terlengkap, ( Yogyakarta: Pustaka Progresif, 1984), p. 1034

${ }^{6}$ Al-Fayumî, Al-misbah al-Munîr Fî̀ Gharib al-Syarh al-Kabîr li al-Rafi'i, ( Cairo: Mathba'ah al-Amiriyah, 1965), p. 2

7 Yusuf al-Qardlawî, Al-Fatwa Bain Al-Indlibath Wa Al-Tasayyub, (Mesir: Dar al-Qalam, tt), p. 5.

${ }^{8}$ Abu Al-Qasim Mahmud Ibn Umar Bin Ahmad AlZamakhsyarî Jar Allah, Tafsîr al-Kasysyâf, ( t.t: Maktabah Syamilah, t.th), p. 305

9 Departemen Pendidikan Nasional, Kamus Besar Bahasa Indonesia, (Jakarta: Balai Pustaka, 2003), p. 314.
While the definition of the fatwa, according to the MUI Fatwa Commission, is an explanation of Islamic law or teachings about the problems faced or asked by the community and is a guideline in carrying out the teachings of his religion. ${ }^{10}$

There is three formula that must be in the fatwa: first, the fatwa leader (mustaftî) both individual and group. Second, the fatwa giver (muftî) with some conditions given by the scholars, and the third fatwa material. ${ }^{11}$ These three elements must exist; if one of these elements does not exist, then it is certain that the fatwa cannot come out.

\section{Method of Establishing Fatwa of the Indonesian Ulema Council}

To perform its duties as a fatwa giver, MUI has the rules of the game contained in the Fatwa Determination Procedure Guidelines that were decided on January 18, 1986. The guidelines were updated with the Guidelines for the Determination of fatwas of the Indonesian Ulema Council, which was decided on October 2, 1997, in Jakarta., ${ }^{12}$ and refined again with the title "Guidelines and Procedures for the Establishment of MUI Fatwa” in 2001. ${ }^{13}$ Finally, this guideline was

${ }^{10}$ Ma'ruf Amin, Pengantar Komisi Fatwa dalam Fatwa Munas VII Majelis Ulama Indonesia, ( Jakarta: Majelis Ulama Indonesia, 2005), p. v

${ }^{11}$ Muhammad Abu Zahrah, Ushûl al-Fiqh,( Mesir: Dar al-Fikr al-Arabi, 1958), p. 401-402. Wahbah alZuhaili, Ushîl al-Figh al-Islâmiy,(Beirut: Dar al-Fikr alMu'asir, 1986), II, p. 1156-1158. See. Amir Syarifuddin, Usûl al-Fiqh (Ciputat: Logos Wacana Ilmu, 2001), II, p. 431-433.

12 This guideline was established by the Leadership Council of the Indonesian Ulema Council through the Decree of the Board of Leadership of the Indonesian Ulema Council number: U-596/MUI/X/1997 dated October 2, 1997. See. Directorate General of Islamic Community Guidance and Hajj, Himpunan Fatwa Majelis Ulama Indonesia, (Jakarta: Departemen Agama RI, 2003), p. 1, 2

${ }^{13}$ As a result of the Fatwa Commission Meeting 
refined through the Ijtima' Ulama Forum of the Fatwa Commission all over Indonesia I, which took place on 20-22 Shawwal $1424 \mathrm{H} /$ December 14-16, 2003 AD in Jakarta. ${ }^{14}$

As stated in the Guidelines for establishing MUI fatwas, mui fatwas are determined based on the Qur'ân, hadith, ijma' and qiyas. Fatwasetting activities are carried out collectively by an institution called the "Fatwa Commission", and the establishment of MUI fatwas is responsive, proactive, and anticipatory. ${ }^{15}$ Unlike the definition of fatwa in general, whose basis is the question of mustafti, because it is passive. With these three traits, Mui fatwa is required to be active, not just waiting for questions or complaints from mustafti.

The establishment of fatwa is based on the Qur'an, sunnah (hadith), ijma', and qiyas, while the method of establishing fatwa is through five steps. ${ }^{16}$ Before the fatwa is established, the first step should be reviewed first the opinion of the imams of the school on the matter to be fatwa, carefully following the propositions. From this, understandably, the MUI fatwa has transmission and continuity with the problems that are stipulated by the imams of the school. This method confirms MUI as the heir to the scientific tradition of previous generations of scholars while confirming the consistency of

Decision, on 23 Muharram 1422/12 April 2001.

14 See. The decision of Ijtima' ulama of the First Indonesian fatwa commission in 2003 in The decision of Ijtima' ulama of the First Indonesian fatwa commission in 2003 in: Himpunan Fatwa Majelis Ulama Indonesia, p. $713-719$

${ }^{15}$ In verse 1,2 and chapter II on the general basis and nature of fatwas. See. Pedoman dan Prosedur Penetapan Fatwa Majelis Ulama, dalam : Ma'ruf Amin, Himpunan Fatwa Majelis Ulama Indonesia Sejak 1975 (Jakarta: Erlangga, 2011), p. 937

16 The General Basis for the establishment of fatwas is contained in chapter II and the Method of Fatwa Management in chapter III. "Pedoman dan Prosedur Penetapan Fatwa Majelis Ulama”, in Ma'ruf Amin, Himpunan Fatwa Majelis Ulama Indonesia Sejak 1975 (Jakarta: Erlangga, 2011), p. 937
MUI in carrying out the functions of the heirs of the prophets. (waratsah al-anbiya'), ${ }^{17}$ by following the traditions and knowledge of the predecessor scholars (salaf al-shalih). This normative guideline seems to be in line with the reality of the mui fatwa commission administrators' scientific background because the majority are of the background of the discipline of fiqh, especially the Shafi'i school. Most Muslim communities in Indonesia legally follow the Shafi'i school, while in religious doctrine following Asy'ary theology. ${ }^{18}$

This is supported by the fact that almost all writings in Arabic about figh and Islamic law, which are used in Islamic educational institutions in Indonesia, are the works of scholars from the Shafi'i school. This list of books includes, among other things; Minhaj al-Talibin by al-Nawawi (d. $679 \mathrm{H})$ with his khulashah and hasyiyah, Namely Kanz alRaghibin by al-Mahalli (w. 864 H), Syarh Kanz al-Raghibin by Qalyuby and 'Umairah, Minhaj al-Thullab by al-Anshary (w. $926 \mathrm{H}$ ), Fath al-Wahhab by al-Anshary (w. $926 \mathrm{H}$ ), Tuhfah al-Muhtaj by Ibn Hajar al-Haitsami (w. $973 \mathrm{H}$ ), Mughni al-Muhtaj by Syarbani (w. $977 \mathrm{H}$ ), and Nihayah al-Muhtaj by alRamli (d. 1004 H). ${ }^{19}$

The second step of the apparent law (alahkam al-qath'iyyat) should be delivered as

${ }^{17}$ In the Insight of the Indonesian Ulema Council mentioned that MUI acts as the heir of the duties of the Prophets, namely spreading the teachings of Islam and opposing the realization of a daily life wisely and wisely based on Islam. See. Secretariat of the Central Indonesian Ulema Council, Himpunan Keputusan Musyawarah Majelis Ulama Indonesia VII, (Jakarta: Majelis Ulama Indonesia, 2010), p. 31

${ }_{18}$ Mohammad Atho Mudzhar, Fatwa-Fatwa Majelis Ulama Indonesia: Sebuah Studi tentang Pemikiran Hukum Islam di Indonesia (1975-1988), (Jakarta: INIS, 1993), p. 19.

19 Mohammad Atho Mudzhar, Fatwa-Fatwa Majelis Ulama Indonesia: Sebuah Studi tentang Pemikiran Hukum Islam di Indonesia (1975 - 1988), (Jakarta: INIS, 1993), dwibahasa, p. 19. 
it is. The third step, in the problem that occurred khilafiyah among the schools, then taken two ways:

a. The establishment of fatwas is based on the results of efforts to find common ground among the opinions of the school through methods al-jam'u wa al-taufiq; ${ }^{20}$ and

b. If the discovery of common ground is not successful, the determination of fatwa is based on the results of tarjih through the muqaranah al-madzahib method using the rules ushul al-fiqh al-muqaran.

The fourth step, in a matter of no legal opinion among the schools, the establishment of fatwas are based on the results of ijtihad jama'i (collective) through the method of bayani, ta'lili (qiyas, istihsan, ilhaqi), istishlah, ${ }^{21}$ and sadd al-dzariah. ${ }^{22}$

Moreover, the fifth step, the determination of fatwas must always pay attention to the public benefit (mashalih'ammah) and maqashid al-syariah. ${ }^{23}$

In the context of consideration of public benefit (mashalih 'ammah) and maqashid al-

20 The method of al-jam'u wa at-taufiq means to compromise between two opinions that seem contradictory, or the same practiced according to the context. See. Aan Supian, Konsep Syadz..., p. 61.

${ }^{21}$ The bayâni method is the attempt to find the law in the text by the study of language; The ta'lîli method also called qiyâsi is the attempt to find the law through the discovery of 'illat and associate it with the law in the text; And the istislâhi method is an attempt to find the law by considering the element of good in it. Further see. Wahbah al-Zuhaili, Usûl al-Fiqh al-Islâmi, (Damaskus: Dar al-Fikr, 1426 H/2005 M), Juz 2, p. 330

22 Sadd al-dzari'ah is a method of establishing the law by closing the road that leads to acts that bring about mafsadah and which are forbidden. Al-Syathibi, Al-Muwafaqat fi Ushul al-Syari'at, (Beirut: Dar al-Rasyid al-Haditsah, t.t.), juz 3, p. 257-258.

${ }^{23}$ Contained in chapter III paragraphs $1-5$ on the Method of Fatwa Determination. See. Pedoman dan Prosedur Penetapan Fatwa Majelis Ulama, in: Ma'ruf Amin, Himpunan Fatwa Majelis Ulama Indonesia Sejak 1975 (Jakarta: Erlangga, 2011), p. 937 shariah, then in establishing fatwas that have been ongoing, fatwas promulgated by the MUI Fatwa Commission should not conflict with nash and the principle of good. In other words, the consideration of benefit becomes one of the main benchmarks.

\section{Reform of Islamic Family Law}

Family law issues are one of the many domestic problems that get a lot of attention fiqh, because many intersect with the text, is very dynamic considering it belongs to social problems. In general, the fiqh rule explains to us that "the original law in the matter of mu'amalah is permissible". However, in the context of the family applies a specific fiqh rule, namely, "al-asl fi al-abdla' al-takrim" (the original law in the matter of intercourse is haram $)^{24}$

In addition, the issue around marriage and family is one of the issues that continue to be actual to be discussed and discussed, considering that it is as old as the age of human history itself and will only end when human life ends. Marriage is in line with the human nature to breed and the desire to vent the desire humanely but considering humans as religious beings. The activities of human life are not separated from the guidance and rules of religion. ${ }^{25}$

As an essential part of Islamic law, family law does not escape the idea of renewal as with the rest of Islamic law. The renewal of Islamic family law has become a globalized discourse throughout the Islamic world, particularly in Indonesia. In the sense that the renewal of Islamic law has become an issue of the most

${ }^{24}$ Maruf Amin, Fatwa dan Perubahan Sosail, dalam Fatwa-fatwa masalah Pernikahan dan Keluarga, ( Jakarta: Elsas, 2008), p. xviii

25 Asrarun Ni'am Sholeh, Fatwa-fatwa masalah Pernikahan dan Keluarga, ( Jakarta: Elsas, 2008), p. v 
hotly talked about modernization movement in the Islamic world. Nevertheless, in the process, it cannot be separated from the various aspects that surround the idea of reforming Islamic family law. Various terms are often used to describe Islamic reform movements, such as "reform," purification," renewal," rethinking Islam, ${ }^{26}$ the resurgence of Islam, ${ }^{27}$ many more. Reform has the understanding of reshaping new understandings as anti-tesa of old patterns of understanding. Correspondingly, the authors of Islamic thought movements, such as the Islamic Unity, call it Islamic reform. ${ }^{28}$ The word purification is more directed at the field of creed and worship based on the consideration that the development of history has brought about the increasing blurring of the purity of faith and worship and the emergence of khurafat and heresy so that efforts are needed to restore the understanding of Islamic teachings to their original form. At the same time, the term renewal is an attempt to re-understand the source of Islam by breaking away from old understanding with a view to re-converting Islam in looking to the future. The word renewal contains a description of the target of renewal aimed at the development of Islamic thought derived from the Qur'an and hadith of the Prophet (peace be upon him). Therefore,

26 Mohammed Arkoum, Rethinking Islam: Common Questions Uncommon Answers, Translated and Edited by Robert D. Lee (Colorado and Oxford: Westview Press, 1994). p. 21

27 Another term is tajdîd or islah. Tajdid is usually interpreted as "renewal" and islah means "reform". Simultaneously the two words reflect a continuing tradition of revitalizing Islamic practices and beliefs in Muslim communities. It provides the basis for the belief that the movements of renewal remain a legitimate part of the elaboration of Islamic revelation in history. See., John O. Voll "Renewal and Reform in Islamic History, Tajdid and Islah,” in John L. Esposito (ed.), Voices of Resurgence Islam (Oxford: Oxford University press, 1983), p. 32.

${ }^{28}$ Howard M. Federspiel, Persatuan Islam: Pembaharuan Islam Indonesia Abad XX, terj. Yudian W. Asmin dan Affandi Mukhtar (Yogyakarta: Gadjah Mada University Press, 1996), p. 13 the renewal is not intended to question the validity of the source of Islamic teachings but rather an attempt to change the pattern of thought of Muslims so as not to be rigidly bound to the pattern of understanding and thinking of the past. ${ }^{29}$ This reform arises due to significant changes in all areas of human life brought about by the rapid advances taking place in the fields of science and technology. ${ }^{30}$ According to Sharon Shiddiq, one implication is the emergence of vigorous efforts to provide a harmonious society based on an aspirational system of law. ${ }^{31}$

More specifically, Iskandar Usman underlined that the core renewal of Islamic law is ijtihad. Ijtihad is interpreted as an attempt to establish a law to answer new problems and developments by returning to the Qur'an and hadith and should not be bound by the provisions of Islamic law resulting from the previous clerical ijtihad. Thus, it is expected that the provisions of Islamic law produced in this way will be able to answer the problems of the ummah and realize the benefits at the core and purpose of Islamic law. ${ }^{32}$

The renewal of family law needs to be done to answer contemporary problems that are one of the characteristics of progressive Muslims. ${ }^{33}$

29 Ridwan Lubis dan Syahminan, Perspektif Pembaharuan Pemikiran Islam (Medan: Pustaka Widyasarana, 1994), p. 7-8.

${ }^{30}$ Harun Nasution dan Azyumardi Azra, Perkembangan Modern dalam Islam (Jakarta: Obor, 1985), p. 1.

31 Abdul Aziz (ed.), Gerakan Kontemporer Islam di Indonesia (Jakarta: Pustaka Firdaus, 1989), p. 1.

32 See. Iskandar Usman, Istihsan dan Pembaharuan Hukum Islam (Jakarta: Rajawali dan LSIK, 1998), p. 111.

33 There are six characteristics of progressive Muslims, namely; (1) Conduct contemporary ijtihad in order to answer contemporary problems; (2) they adopted, the view that some areas of traditional Islamic law require substantial changes and reforms in order to adapt to the needs of today's Muslim communities; (3) combining traditional Islamic scholarship with modern Western thought and education; (4) believe that social change, whether in the intellectual, moral, legal, economic or 
Because various contemporary problems in the field of family law are often not answered conclusively by classical figh and the changes that occur in society so quickly because of science and technology. For Islamic law to remain actual to govern the lives of Muslims today, Islamic law is needed in its new form and does not have to take over all the old fiqh. ${ }^{34}$ This means that it is intended to be held as a family law renewal effort. To achieve that, of course, will not be able to escape the role of the fiqh proposal with its ijtihad as the foundation of figh.

After Indonesia's independence, many legal reform efforts were also directed to changes in the written law of colonial relics to be used as national law. Islamic law was used as one of the elements of national law that served as a reference informing the national law. This effort has resulted in Law No. 1 of 1974, which has been changed to Law No. 16 of 2019 on marriage law. Then, in 1989 also formed Law No. 7 of 1989, popularly known as the Religious Justice Act (UUPA), which aligns the position of the Religious Court with the General Court and places Islamic law as one of the elements in national law. In 1991 there was also a Compilation of Islamic Law regarding family law, which consists of marriage law, inheriting, and representation. In the attempt to compile the law, the tendency to one of the schools (especially the Shafi'i school) began to be set aside, but more emphasized on good, and even a law reform has been carried out.

technological spheres, should be reflected in Islamic law; (5) Not to bind himself to a particular school of law and theology in his approach to study; and (6) they placed a press point of their thinking on social justice, gender justice, human rights, and harmonious relations between Muslims and non-Muslims. See. Saeed, Islamic Thought An Introduction, ( London and New York: Routledge, 2006), p. $150-151$.

${ }^{34}$ Amir Syarifuddin, Usul Figh (Jakarta: Logos Wacana Ilmu, 2001), Jilid. II, p. 254.
For example, among others, in the law of inheritance, parents/adopted children are entitled to participate in receiving the relics of children/adoptive parents as much as $1 / 3$ part as a mandatory will.

Moreover, in the law of marriage, it is only permissible to be married by a 19-year-old man and a woman who is 16 years old, and many more. Then the age of marriage for women was raised to 19 years, following law no. 16 of 2019 amendment to law no. 1 of 1974 on marriage.

\section{Scholars' Views on Marriages of Different Religions}

In classical literature, there is no known term marriage of different religions. However, discussions related to the issue are included in the discussion section on women who are forbidden to marry or marriages forbidden, which among others are referred to as azzawâj bi al-kitabiyât, az-zawâj bi al-musyrikât or az-zawâj bi ghaer al-muslimah (marriages with women of the Book (read: Jews and Nashrani), marriages with pagan women (musyrik people) marriages in the book (read: Jews and Nashrani), and marriages in the book, marriages with pagan non-Muslim. ${ }^{35}$

The marriage of different religions is intended here between someone who is Muslim (Muslim) and a non-Muslim (nonMuslim). The Qur'an divides the non-Muslims in this discussion into three categories: the pagans, infidels, and the people of the book. ${ }^{36}$ In general, the understanding of Musyrik is attached to groups that support God or

35 Muhammad Khaeruddin Hamsin, Perkawinan Beda Agama dalam Tinjauan Syariah dan Hukum Positif (Menyoal Pasal 2 ayat (1) UU No. 1 Th. 1974), Papers not published, p, 3.

36 Tutik Hamidah, "Pemikiran Feminis Muslim Indonesia", Disertasi UIN Syarif Hidayatullah Jakarta, 2009, p. 148. 
acknowledge the existence of God other than Allah SWT, such as pagans, fire-worshippers, and many more. Infidels are generally defined by all those who are not Muslims. At the same time, the book expert is a group of adherents of religions that have scriptures or adherents of pseudosic religions, such as Jews and Christians ${ }^{37}$.

In addition to the term Ahl Al-Kitab, the vocation used by the Qur'an against Jews and Christians is to use the terms utû al-Kitab, utû nashiban min al-kitâb, Al-Yahûd, Al-Ladzina Hâdû, Bani Isrâil, An Nashâra, and other terms. The word Ahl Al-Kitab is repeated in the Qur'an thirty-one times, utû Al-Kitab eighteen times, Utû nashiban min al kitab three times, Al-Yahud eight times, Al-Ladzina Hâdû ten times, An Nashâra fourteen times, and Banu Isrầil forty-one times. ${ }^{38}$

The marriage of different religions has long been a controversial issue in Islamic history. The views of the scholars on this subject can be grouped into three opinions. First, it prohibits absolutely both those categorized as pagans and experts of the book. The ban applies to both Muslim women and Muslim men. Second, allow it on condition. Several scholars allow the marriage of Muslim men and nonMuslim women on the condition that nonMuslim women are from the expert group of the book, but not the other way around. Third, some other scholars allow marriage between Muslims and non-Muslims, and that ability applies to both men and women. ${ }^{39}$

\footnotetext{
${ }^{37}$ Tutik Hamidah, "Pemikiran Feminis..., p. 148.

${ }^{38}$ Quraish Shihab, Wawasan Al-Quran Tafsir Maudhu'i atas Pelbagai Persoalan Umat, (Bandung: Mizan, 1996 ) p. 347.

39 Including those who forbid is Ibn Umar, and who obtained on condition that the woman of the book is jumhur ulama. see. See. 'Ala al-Din 'Ali bin Muhammad bin Ibrahim al-Baghdadî al-Khâzin, Tafsîr al-Khâzin, (Bairut: Dar al-kutub al-Ilmiyah, $1415 \mathrm{H}$ ), Jilid II, p. 15. 'Ali al-Shabuni, Tafsir ayat al-Ahkam,
}

The argument of the first group that prohibits marriage of different religions, both for Muslim women and Muslim men, both categorized as musyrik and book experts are:

i. The Word of Allah (swt) in the Qur'ân Surat Al-Baqarah (2): 221 is:

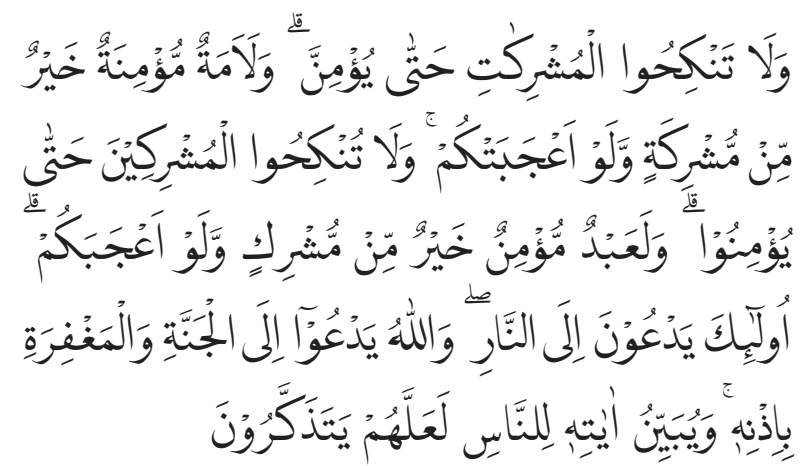

"And do not marry women before they believe. Surely a believer is better than a woman of idolak, even if She attracts your heart. Furthermore, do not marry the wicked before they believe. Surely the believer is better than the polytheists, even though He draws your heart. They go to hell, while God invites them to heaven and forgiveness with His permission. And Allah explained His verses to men so that they might learn a lesson." (QS. Al-Baqarah [2]: 221)

As for a reason for the descent of this verse as narrated by Ibn Munzir, Ibn Abi Hatim and al-Wahidi of Maqatil said: "The descent of this verse is related to Ibn Abi Mursyid al Ghanawi who asked permission to the Prophet (peace be upon him) to marry 'Inaq, while she was a beautiful woman who was rich again, then this verse came down. ${ }^{40}$ Adherents of this opinion do not distinguish between musyrik and the expert of the book because the two groups are in reality the same, as the statement of the Prophet's friend 'Abdullah ibn 'Umar:

(Damascus: Dar al-Fikr, t.th), Jilid I, p. 248

${ }^{40}$ Abu al-Hasan 'Ali ibn Ahmad al-wâhidî, Asbâb Nuzûl al-Qurân, (Kairo: t.p., 1968) p. 45-46, 


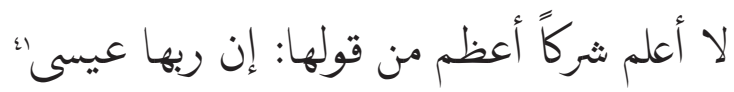

"I know no greater harm than the one who claims that his Lord is Isa".

Thus, according to this group, Christians and Jews belong to the pagans, not the book members, because in practice, they have worshiped anything other than Allah in the sense of doing Shirk. The Christians killed Jesus, while the Jews killed Uzair. ${ }^{42}$

According to Muhammad Abduh, among the reasons for not a Muslim marrying a polytheist is because they seem to immediately close their ears as soon as they hear the invitation of Islam, their hearts are loud and immediately turn away, do not want to know the teachings of Islam, because indeed their minds are already jumud, their hearts are closed and if they marry a Muslim man then most likely he is unfaithful, Not keeping his promises and will betray her husband and his property, he will not hesitate to do heinous and do whatever he wants, so it is forbidden to marry a woman who is divorced. ${ }^{43}$

Another reason for the prohibition of marriage with non-Muslims is the difference in faith; marriage is intended to establish a harmonious relationship, at least between a married couple and his children. How can harmony be achieved if the values embraced by husband and wife are different, contrary to the values embraced by the husband and wife? Values color a person's thoughts and behavior. In the Islamic view, the value of the Supreme Godhead is the highest value, which,

${ }^{41}$ Abu Abdullah Muhammad bin Umar bin Al-Hasan al-Taimi al-Razi, Mafâtih al-Ghaib, ( Bairut: Dar Ihya Turats al-Arabi, t.th), Jilid I, p. 1612

42 'Abd al-Razzaq bin Hamma al-Shin'ani, Tafsir alQur'an, (Riyadh, Maktabah al-Rusyd, 1410), chapter II, p. 271

${ }^{43}$ Muhammad Abduh, al-'A'mâl al-Kâmilah..., jilid IV, p. 586 however, should not be sacrificed. It should be preserved and passed on to posterity. If one partner does not believe this value, then how can it be passed on to posterity?

On the other hand, if this view of life is not realized in real life, is there still any other value that will be realized and practiced? Can one tolerate the core of a belief or even sacrifice it in the name of love or out of admiration for beauty or good looks, possessions, and social status? All that is admired does not last. The marriage is expected to last. Lasting and brought to death is faith, therefore for the lasting of marriage, then something lasting must be the foundation. That is also why the above verse says: Women whose social status is low, but believe, are better than women whose social status is high, beautiful, and rich, but without faith. This statement Allah conveys with the "true" confirmation editor. ${ }^{44}$

The second group that allows the marriage of Muslim men with non-Muslim women from among the members of the book by arguing in the Qur'an surah Al-Ma'idah verse 5:

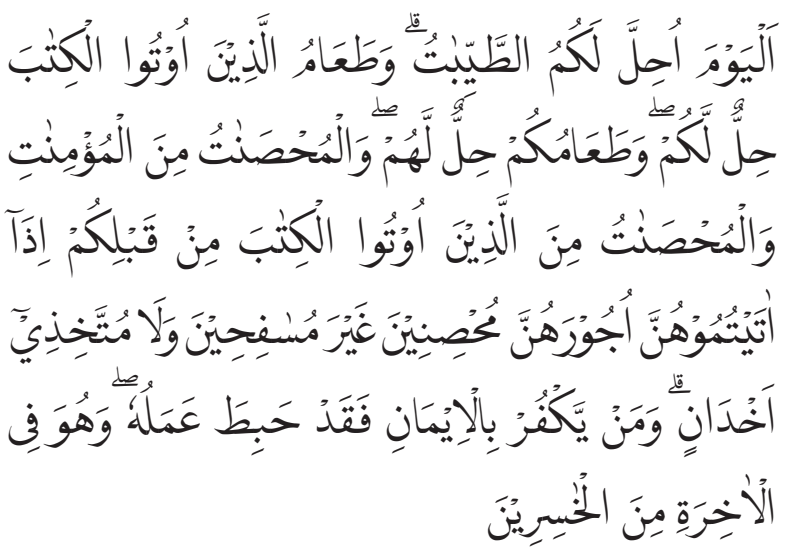

"Today is good for you. The food of those given the Book is lawful to you, and your food is lawful for them. (and It is dihalalkan mangawini) Women who maintain honor among women of faith and those who maintain honor among

${ }^{44}$ M.Quraish Shihab, Tafsir al-Misbah Pesan Kesan dan Keserasian Al-Qur'an, (Bandung: Mizan, 2000), Vol. I, p. 445 
those who were given the Book before you, if you have paid their dowry to marry him, not with the intention of adultery and not (also) making him a mistress. Whoever disbelieves after believing (does not accept the laws of Islam) then removes his practice and he on the Day of Resurrection is among those who lose money. (QS Al-Ma'idah [5]: 5)

Ali al-Shabuni said: "The above verse expressly speaks of the marriage of a Muslim man married to a woman of the book, and this verse is the proposition held by jumhur ulama." ${ }^{45}$ Muhammad 'Ali al-Sayis agreed:

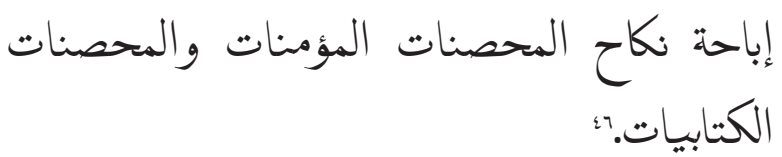

"(This verse explains) the ability to marry a believer woman who maintains her honor and the ability to marry a woman who maintains honor."

As for the marriage of Muslim women with men, the book's expert is not explicitly stated in this verse. It concludes that the marriage of Muslim women and men of the book is forbidden; if allowed, it is indeed stated expressly in verse. ${ }^{47}$

The scholars who allow the marriage of Muslim men with women of the book still different opinions about who is meant by the book's expert in the verse. Imam Shafi'i chose the term ahl al-kitab as jews and Christians of the descendants of the Israelites, excluding other nations who adhered to Judaism and Christianity. His reason, among other things, was that Moses and Jesus were only sent to them, not to the Gentiles. Also, there is an

45 'Ali al-Shabuni, Tafsir Ayat al-Ahkam, (Damascus: Dar al-Fikr, t.th), Jilid I, p. 248

46 Muhammad 'Ali al-Sayis, Tafsir Ayat al-Abhkâm, (Mesir: Maktabah al-Ashriyah, 2002), p. 354

47 Sayyid Sabiq, al-Fiqh al-Sunnah, (Kairo: Dâr al-Fikr, 1997), jilid II, p. 94. editor min qablikum (before you) in the verse that allows the marriage. ${ }^{48}$ Imam Shafi'i's opinion is different from the opinion of Imam Abu Hanifah and the majority of legal experts who state that anyone who believes in one of the Prophets or the book that Allah has sent down then he is an expert of the book. ${ }^{49}$ Thus, ahl al-kitab is not limited to Jewish or Christian groups.

Muhammad Rashid Ridho when interpreting QS. Al-Maidah verse 5 outlined at length the legal issue of marrying a woman who is a member of the book. After detailing and assessing widely the stories put forward by the Companions of the Prophet and tabi'in, the rules of ushul and language, and listening and weighing the opinions of the previous scholars, he issued the following fatwa:
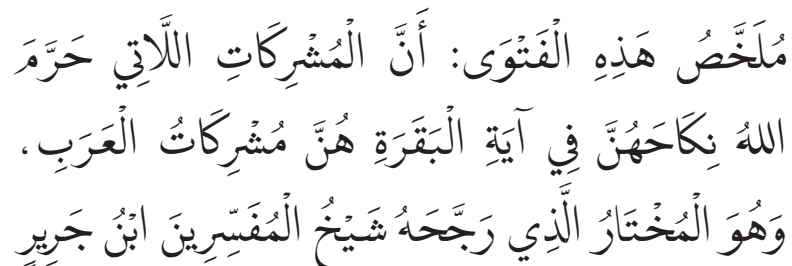

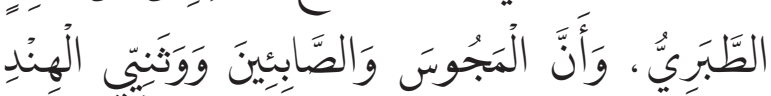

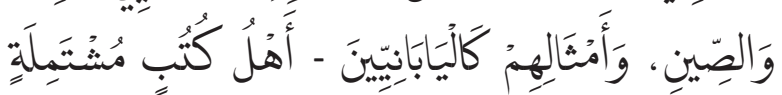

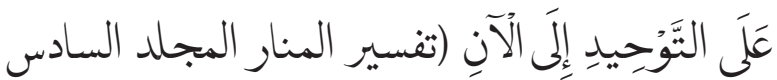
०.(1.) $ص$,

"The conclusion of this fatwa is that the pagan women forbidden by Allah to marry him in Surat Al-Baqarah verse 221 are arab women of deliberation. That is the choice strengthened by the supreme teacher of the mufassir Ibn Jarir Ath-Thabari, and that the Magi, Ash-Shabiin, pagans in India, China and like them like the

${ }^{48}$ Quraish Shihab, Wawasan Al-Quran Tafsir Maudhu'i atas Pelbagai Persoalan Umat, (Bandung, Mizan, 1996) p. 483

${ }^{49}$ Quraish Shihab, Wawasan Al-Quran..., p. 483

${ }^{50}$ Muhammad Rasyid bin Ali Ridho, Tafsîr al-Manâr, (Mesir: Al-Hai'ah al-Mishriyah al-Ammah Lil Kitab, 1990), Jilid VI, p. 160 
Japanese are Abl Al-Kitab which (their book) contains the teachings of tawhid until now"

Al-Qasimî when interpreting surat Al-Tîn, he explained that while scholars of his time understood the word Al-Tin as a tree (in which) the founder of Buddhism (obtained divine revelations), he later asserted that:

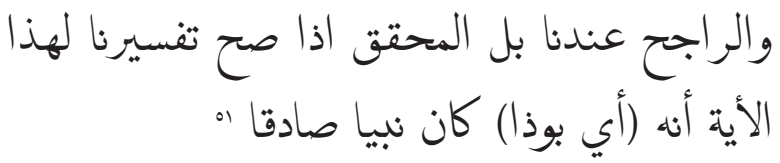

"And the stronger in our view is even inevitable, if our interpretation is accurate, that he (Buddha) is a true Prophet"

While Mahmud Syalthut argued that the marriage of Muslim men with women of the book is allowed as one of dawah's strategies, in their position as husbands, men have the right to educate their families, wives, and children with Islamic morals. The marriage is expected to disbelief rescind the hatred and resentment of non-Muslims against Islam, especially in wives' hearts. Likewise, the wife, with her husband's good treatment of her, is expected to know the beauty and goodness of Islam and that Islam gives perfect rights to the wife. However, if that hope cannot be realized, marriage should be banned. ${ }^{52}$

Other reasons can be expressed, as maulana Muhammad Ali revealed. According to him, although not explicitly mentioned in the revelation of IIahi, in practice, most Muslims did not approve of the marriage of Muslim women to non-Muslim men in the past. The disagreement is based solely on the ijtihad that a Muslim woman married to a non-Muslim man will find it difficult in a non-Muslim family because it will lose the rights they

51 Muhammad al-Qasimi, Mabâhis At-Takwîl, (Damascus: Dar al-Fikr, 2001), Jilid XVII, p. 6201

52 Mahmud Syaltut, Min Taujihât Al-Islâm, (Kairo: al-Idarah al-Amah, 1959), p. 253. previously enjoyed if they were in the family environment. A wife will follow her husband's traditions, and the husband will influence her status as a Muslim woman. ${ }^{53}$

The third opinion, which allows Muslim marriage with non-Muslims, is limited to men and women. This group also refers to the three verses that have been used by the two previous groups, namely QS Al-Baqarah (2): 221; Al-Mumtahanah (60): 10; and AlMa'idah (5): verse 5. What is different is the way it is interpreted. This group put forward some arguments. First, Surah Al-Baqarah (2): 221 only forbids the marriage of a Muslim to Musyrik. Muhammad 'Abduh and Rashid Ridha explained that what is meant by the women of deliberation in Al-Baqarah (2): 221 is limited to Arab women in the time of the Prophet. The indication that in the text of the verse and mentioned the prohibition of marrying people is also followed by the advice to marry with slaves. The context is the pagans of the Prophet's time, and they no longer exist today, as do the slave groups. Another view concerns Surah Al-Baqarah (2): 221 that it has been naskh (canceled) by Surah Al-Ma'idah (5): 5. The first surah was revealed earlier. ${ }^{54}$

Second, Surah Al-Ma'idah (5): 5 allows Muslim men to marry women of the book, and the ability is undoubtedly understood to apply to the opposite. In Arabic, a style of language is commonly called al-iktifa; It is enough to mention some of it and from there is understood other parts. For example, in verse it is stated that Muslim men can marry women of the book, then the mafhum mukhalafah of Muslim women is not hindered

${ }^{53}$ Maulana Muhammad Ali, Qur'an Suci: Teks Arab Tarjamah dan Tafsir ( Jakarta: Dar al-Kutub al-Islamiyah, 1993), p. 119.

${ }^{54}$ Muhammad Rasyid bin Ali Ridho, Tafsîr al-Manâr, (Mesir: Al-Hai'ah al-Mishriyah al-Ammah Lil Kitab, 1990), Jilid II, p. 351. 
from marrying men of the book. ${ }^{55}$

Third, Surah Al-Mumtahanah (60): 10 explicitly explains the prohibition of perpetuating marital relationships with infidel women. Suppose we understand the context of the time of the verse's descent. In that case, this prohibition is very reasonable considering that the infidel Quraysh are very hostile to the Prophet and his followers. At that time, the context was a war between the Believers and the Infidels. The prohibition on perpetuating relationships are intended to be identified where the enemy and which friends. Therefore, this verse must be understood contextually. If the conditions of war no longer exist, then the prohibition is uprooted by itself. Another argument relates to Surah AlMumtahanah (60): 10 that it has been passed by Al-M'a'idah (5): $5 .^{56}$

\section{MUI Fatwa Ruling on Marriage of Different Religions}

In the 7th MUNAS MUI, which took place on 19-22 Jumadil End of $1426 \mathrm{H}$. I 26-29 July 2005M in 2005 in Jakarta, MUI issued 11 fatwas, one of which was a fatwa on Marriage of Different Religions. Mui in its fatwa, stipulates two things: 1). Marriage of different religions is haram and illegitimate. 2 ). The marriage of a Muslim man to a woman Ahlu Al-kitab, according to qaul mu'tamad is haram and illegitimate. Which is the subject of MUI consideration to issue this fatwa there are four things; 1). Lately, it is suspected that there are many different religious marriages; 2) that marriage of different religions contains differences among fellow Muslims and often invites unrest during society. 3). Amid society,

${ }^{55}$ Muhammad Rasyid bin Ali Ridho, Tafsîr al-Manâr, (Mesir: Al-Hai'ah al-Mishriyah al-Ammah Lil Kitab, 1990), Jilid VI, p. 193.

${ }^{56}$ Maulana Muhammad Ali, Qur'an Suci: Teks Arab Tarjamah dan Tafsir (Jakarta : Dar al-Kutub al-Islamiyah, 1993), p. 119. thoughts have arisen that justify the marriage of different religions under the pretext of human rights and benefits. 4). To realize and maintain the provisions of domestic life, MUI considers it necessary to establish fatwas on marriages of different religions to be used as guidelines.

As for the legal consideration that MUI used as a basis in deciding this fatwa in the form of seven holy verses of the Quran, one hadith of the Prophet (peace be upon him) and one Qaeda fiqhiyah, and paying attention to the decision of the MUI fatwa in munas II in $1400 / 1980$ on mixed marriage, as well as the opinion of the commission $\mathrm{C}$ in the field of fatwa in Munas VII MUI 2005. The verses are:

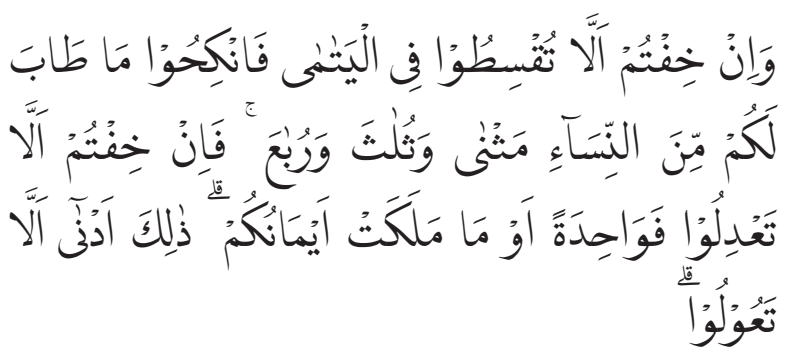

"And if you fear that you will not be able to be fair to an orphaned woman, marry the women you are happy with two, three, or four. Then if you are afraid that you will not be able to be fair, then (marry) only one, or the slaves you have. This is closer to not being persecuted.." (QS. Al-Nisa [4]: 3)

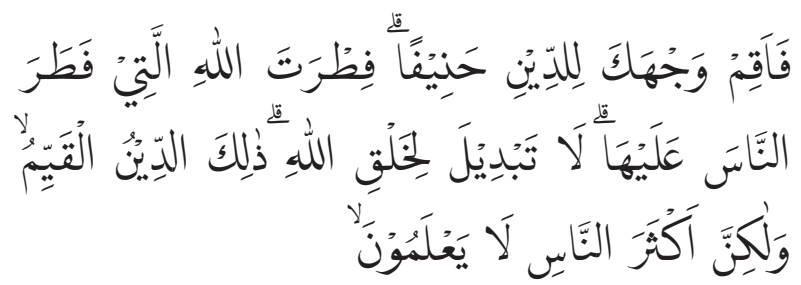

"And among the signs of His power is that He created for you wives of your kind, that you might tend and feel serene in him, and be made among you a sense of love and affection. Indeed there are signs for the people who think." (QS. Ar-Rum [30]: 21) 


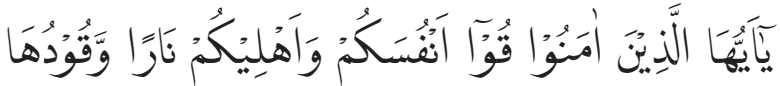

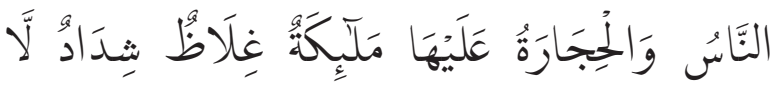

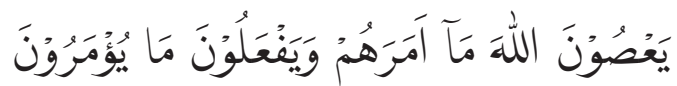
"O you who believe, protect yourself and your families from the fire of hell whose fuel is man and stone; His guards were angels who were rude, challenging, and obeyed God to what He commanded them and always did what he was commanded to do.." (QS. At-Tahrim [66]: 6)

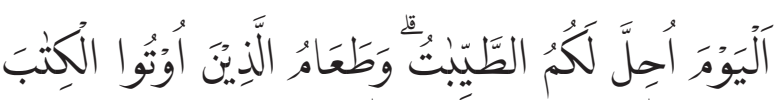

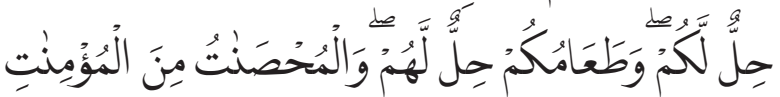

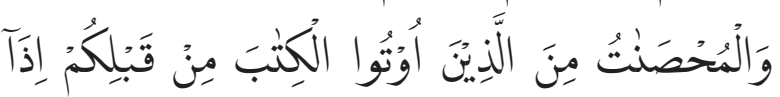

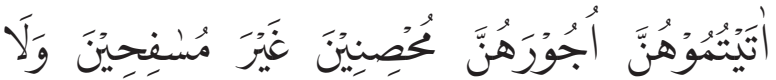

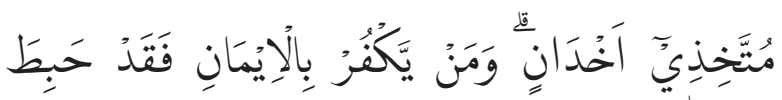

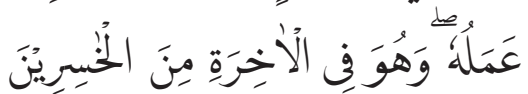

"Today it is done to you who are good. The food of those given the Book is lawful to you, and your food is lawful for them. (and It is dihalalkan mangawini) Women who maintain honor among women of faith and those who maintain honor among those who were given the Book before you, if you have paid their dowry to marry him, not with the intention of adultery and not (also) making him a mistress. Whoever disbelieves after believing (does not accept the laws of Islam) then removes his practice and he on the Day of Resurrection is among those who lose money. (QS. Al-Maidah [5]: 5).

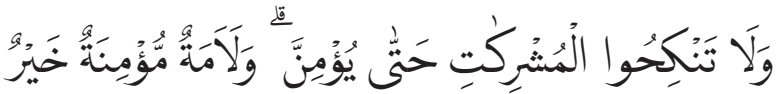

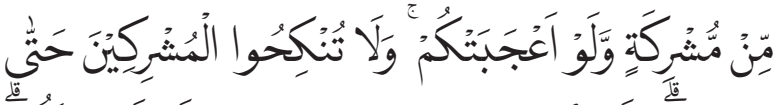

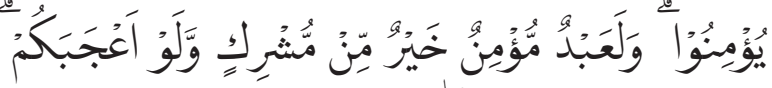

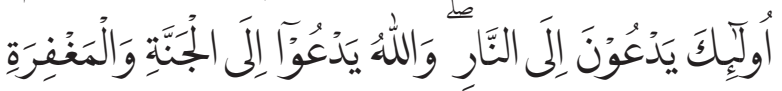

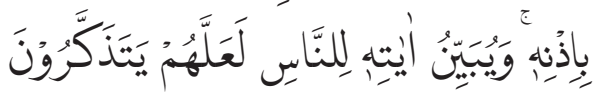

"And do not marry women before they believe.
Surely a believer is better than a woman of idolak, even if She attracts your heart. Moreover, do not marry the wicked before they believe. Surely the believer is better than the polytheists, even though He draws your heart. They go to hell, while God invites them to heaven and forgiveness with His permission. Moreover, Allah explained His verses to men so that they might learn lessons. (QS. Al-Baqarah [2]: 221)

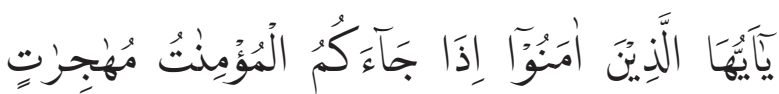

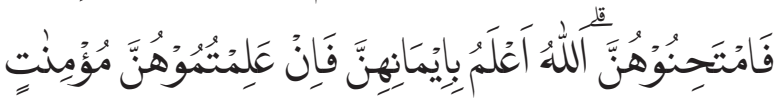

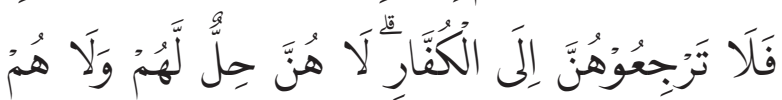

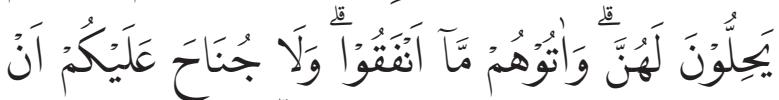

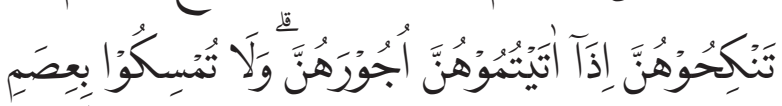

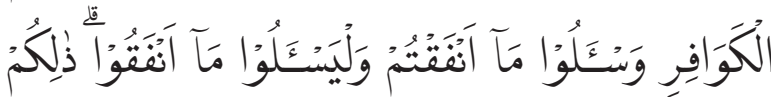

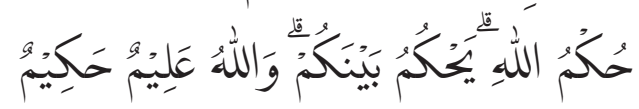
"O you who believe, when you come to migrate to you women who believe, then you shall test them. Allah knows better about their faith; so if you know that they believe, do not return them to the disbelievers. They are not lawful to the disbelievers, and the disbelievers are not lawful to them. Moreover, please give it to them, the dowry they have paid. Moreover, there is no sin against you marrying them when you pay them their dowry. Moreover, please do not stick to the ropes with unbelievers; And ask for the dowry that you have paid; And let them ask for the dowry they have paid for. This is the law of God that he has established among you. Moreover, Allah knows the wise again. (QS. Al-Mumtahanah [60]: 10)

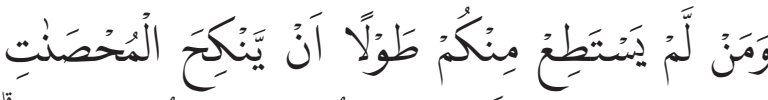

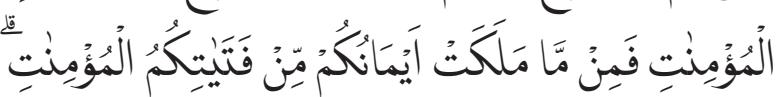

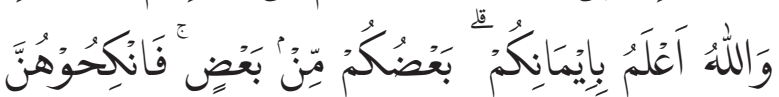

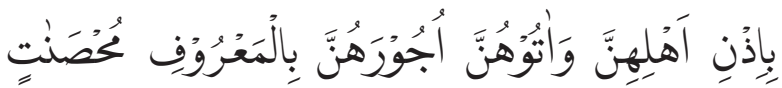




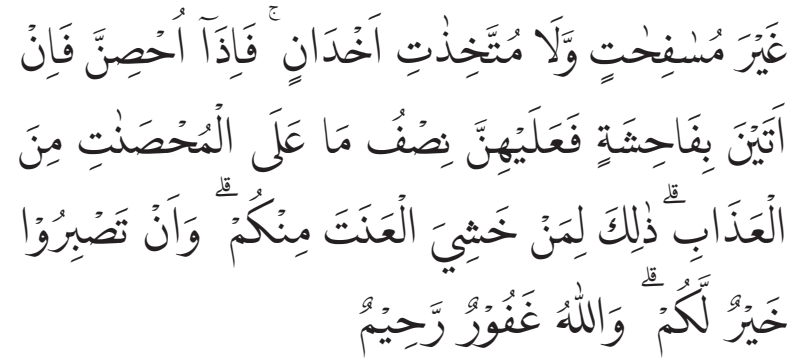

"And whoever among you (the free man) who does not spend enough to marry a free woman again believes, he can marry a woman of faith, from the slaves you have. God knows your faith. Some of you are from others, therefore marry them with the permission of their master, and give them their maskawin as is proper, while they are women who take care of themselves, not adulterers and not (nor) women who take other men as their pets; And when they have taken care of themselves by marriage, then they commit a heinous act (adultery), then upon them half the punishment of the punishment of the married free women. (The ability to marry slaves) is for those who are afraid of the blessing of guarding themselves among you, and patience is better for you. And Allah is merciful again. (QS. Al-Nisa' [4]: 25)

The Prophet explained:

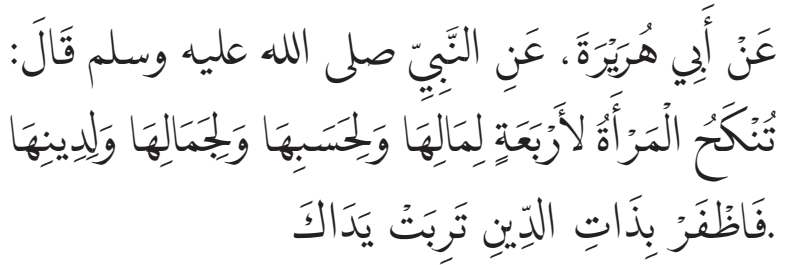

"She was married for four things: because of her wealth, because of the origin of her descendants, because of her beauty, because of her religion. Kama let you hold fast (with women) who embrace Islam; (otherwise) your hands will perish." (HR. Mutafqun' alaih)

Qa'idah Sadd al-Dzari'ah

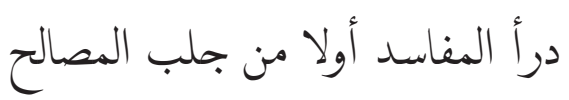

"Preventing existence takes precedence over appealing to benefits".

\section{Relevance of MUI Fatwa Number: 4/Munas VII/MUI/8/2005 On Marriage Of Different Religions with Renewal of Islamic Family Law}

Fatwa On Marriage of Different Religions, which is the result of Munas II MUI held from May 26 to June 1, 1980, has decided to ban marriage of different religions, whether Muslim men with non-Muslim women or vice versa. ${ }^{57}$ Manurut Atho Muzdhar, the release of this fatwa is a response to the increasing public attention to the increasing number of interfaith marriages. So important is this fatwa that talks on this matter are held in annual conferences rather than in the usual meetings of the fatwa commission. ${ }^{58}$ The fatwa contains two clear statements: an Islamic woman is not allowed to marry a non-Islamic man, and vice versa that an Islamic man is not allowed to marry a non-Muslim woman. ${ }^{59}$

After 25 years, the issue was raised again at the Annual Conference on Munas VII in 2005 and established two dictums, namely; First, marriages of different religions are haram and illegitimate. Second, the marriage of a Muslim man to a woman Ahlu Al-kitab, according to qaul mu'tamad, is haram and illegitimate. ${ }^{60}$

Thus, the Indonesian Ulema Council has issued fatwas regarding the marriage of different religions twice. First on Munas II MUI on May 26 to June 1, 1980, AD coincided with the date 11-17 Rajab 1400 H. Second, on Munas VII MUI dated July 28, 2005, to coincide with the month of Jumadil End $1426 \mathrm{H}$.

Seeing the verdict of the MUI fatwa above, in ijtihâd intiqâîy, MUI prefers opinions that

57 M. Atho Muzhar, Fawa-fatwa Majelis Ulama Indonesia, ( Jakarta: INIS, 1993), p. 99

${ }^{58}$ M. Atho Muzhar, Fawa-fatwa..., p. 99

${ }^{59}$ Ma'ruf Amin dkk, Himpunan Fatwa Majelis Ulama Indonesia Sejak 1975, (Jakarta: Erlangga, 2011), p. 45

${ }^{60}$ M.A.Sahal Mahfudh, dkk, Himpunan Keputusan Musyawarah Nasional VII Majelis Ulama Indonesia, (Jakarta: Majelis Ulama Indonesia, 2005), p. 43 
do not allow the marriage of different religions, both between Muslim men and women of the book, Especially between Muslim women and men who are members of the book. Ma'ruf Amin explained: "The impureness of marrying the people of the book is because the Jews and Christians are now among the pagans (watsani). In addition, it is also seen the consequences of mudharat caused by marriage itself, including the future of children; it is feared that children follow the religion of their mothers who are not Muslim, such as the children of Jamal Mirdad, then in order to close the gap of damage (Sadd li ad-dzari'ah), MUI decided according to the opinion that mu'tamad marriage of different religions is not allowed, of course by not ruling out opinions that allow it.

The author can understand the verdict of this MUI fatwa when viewed from the perspective of siyasah syar'iyah of course something is not seen in terms of halal or haram alone, can or cannot, but more than that is to see something in terms of maslahat or not maslahat. Of course, in terms of marriage, the purpose of marriage is to create a harmonious home life full of sakinah mawaddah warohmah. Household harmony cannot be established if married couples do not agree with one ideology, not one view of life and religion.

So according to Muhammad Syaltut the primary purpose of allowing the marriage of a Muslim with a woman Ahl Kitab is so that with the marriage occurs a kind of liaison of love and affection so that eroded from his wife's mind the feeling of unsympathetic to Islam with the excellent attitude of the muslim husband of different religions, so reflected the beauty and primacy of Islam naturally. If the Muslim husband is carried away by the wife, or his child is carried away to him to divert them from the Islamic creed, then this is contrary to the purpose of permissible marriage, and at that time, the marriage is agreed to be dissolved.
In siyâsah syar'iyyah that applies in Indonesia mentioned that marriage of different religions contained in Law No. 1 of 1974 based on religion. That is, the legality of a person's marriage is determined by his religious law. This is following the legal ideals of the Indonesian nation, Pancasila, and the Supreme Divinity mentioned in the opening and formulated in the Body Of The Constitution of 1945 Article 29 paragraph (1) of the Religious Chapter. Article 2 paragraph (1) of the Marriage Act expressly states that "marriage is lawful if performed according to each of its religions and beliefs". Moreover, the MUI fatwa ruling above is in line with the prevailing legislation in Indonesia, Law number 1 of 1974 on marriage and PP. No. 9 of 1975 on the Implementation of Law No. 1/1974 on Marriage and Presidential Instruction No. 1 of 1991 on Compilation of Islamic Law.

The mui fatwa ruling when reviewed with the theory of siyasah syar'iyah is relevant to the renewal of family law in Indonesia. The theory of siyasah Al-Mawardi requires that a siyasah policy protects the people or the wider community. Moreover, it is ulil amri must maintain religion and govern the state. When connected with the MUI fatwa ruling that prohibits marriage of different religions, of course, one of the purposes of the ban is to protect and maintain the religion of their descendants (hifzhu aldin). This is one of the maqashid shariah. In addition, of course, maintaining and protecting the descendants is also the purpose of the Islamic religion (maqashid shariah).

Mui Fatwa on the Prohibition of Marriage of Different Religions has given birth to a family law product that has a side of family law reform in Indonesia. The side of the renewal can be seen in the view of scholars who allow the marriage of Muslim men with women of the book. Alternatively, allow it on condition. However, MUI makes it different, namely prohibiting the marriage of Different 
Religions absolutely and declaring the marriage of Different Religions is not legal.

Another argument that what the MUI is citing is relevant to the Renewal of The Law of Foreign Affairs in Indonesia, and this fatwa has a side of renewal of Family Law is that this fatwa is in line with the content of the KHI which also does not allow marriage between a man and a woman who is not Muslim. This provision is stipulated in article 40, compilation of Islamic law (KHI), namely; "It is forbidden to have a marriage between a man and a woman due to certain circumstances: (a). because the woman in question is still bound by one marriage with another man; (b) a woman who is still in iddah with another man; (c) a woman who is not Muslim." 61

This fatwa is also in line with the contents of the Compilation of Islamic Law (KHI) Article 44, which prohibits Muslim women from marrying non-Muslim men. Expressly mentioned in article 44 of KHI, i.e.;

"An Islamic woman is forbidden to marry a man who is not Muslim." In the implementation in the field, the Marriage Registrar has the right to refuse to perform his duties, as stipulated in article 69 paragraph (1) in the KHI: "If the VAT argues that against the marriage there is a prohibition according to Law No. 1 of 1974 , then he will refuse to hold the marriage". ${ }^{62}$

The following argument that the MUI fatwa has a side of renewal of Family Law and is relevant to the renewal of Family Law in Indonesia that this fatwa is in harmony and in line with the Compilation of Islamic Law (KHI) Article 4 which explains that "Marriage is legal, if performed according to the laws of each religion, following article 2 paragraph (1) of Law No. 1 of 1974 concerning marriage".

\footnotetext{
${ }^{61}$ Islamic Law Compilation (KHI) verse 40

${ }^{62}$ Islamic Law Compilation (KHI) verse 44
}

Article 2 paragraph (1) in question is: "Marriage is legal if done according to the law of each religion and its beliefs." Therefore, this provision of State law (siyasah state) is generally accepted, binding, and negates dissent, ${ }^{63}$ following the rule "Hukm al-Hakim ilzamun wa yarfa'u alkhilaf". (Government decisions are binding to implement and eliminate dissent)."

The MUI fatwa ruling is also in line with the theory of maslahah al-Thufi, which prioritizes the maslahah of nash. Where the Nash Qur'an surah Al-Mầidah [5]:5 allows Muslim men to marry women who maintain their honor, but because in order to maintain the more significant benefit of maintaining the faith (hifzh al-dîn) of children who may be affected and follow the religion of their mother, the MUI decided to ban the marriage.

Marrying a woman who is not a good man because in the past marrying them there is an element of dawah in it. However, it is now challenging to realize this type of marriage impacts the child born later. While the religious tendencies of children today are more influenced by their mothers, not by their fathers. ${ }^{64}$

The provisions of this MUI fatwa can be considered a renewal of family law, considering that in various books of fiqh mentioned a Muslim man is forbidden to marry a woman of musyrikah, but may marry a woman of kitabiyah, namely those who are Jewish and Christian. ${ }^{65}$ In the MUI Fatwa, it is forbidden. That is the critical point of family law reform carried out by MUI through its fatwa. Thus, in the Indonesian legal system, there is no known possibility of the marriage of different religions.

${ }^{63}$ Mufti AM, Pembaharuan Hukum dalam Kompilasi Hukum Islam di Indonesia, Makalah tidak di terbitkan, p. 13

64 Isnawati Rais, Hukum Perkawinan dalam Islam (Cet. I; Jakarta: Balitbang, 2006), p. 120

65 Abdullah Ahmad Qadiry, Nikah Beda Agama Menurut Islam. Terjemahan dari Syaihu Asnawi (Cet. I; Yogyakarta: Media Wacana, 2003), p. 128 


\section{Conclusion}

Based on the study as outlined in the previous discussion, the following conclusions can be expressed:

1. The Fatwa of the Indonesian Ulema Council (MUI), as figh is the result of ijtihad, has contributed significantly in establishing legal norms (religion) and as a guide for Indonesian Muslims. MUI, through its fatwa, has sought to reform Islamic family law.

2. The views of scholars on the marriage of different religions can be grouped into three groups: first, absolutely forbidding; second, allow conditional; Third, allow marriage between Muslims and non-Muslims, both for men and women.

3. This MUI fatwa banning marriages of different religions has given birth to family law that has a side of family law reform in Indonesia. The renewal side can be seen in the MUI's view that marriages of different religions are not legal. Some scholars allow the marriage of Muslim men with women of the book.

\section{References}

Amin, Ma'ruf dkk. Himpunan Fatwa Majelis Ulama Indonesia Sejak 1975, Jakarta: Erlangga, 2011.

Amin, Ma’ruf. "Fatwa dan Kedudukannya Dalam Islam", Makalah, disampaikan pada Konferensi Internasional tentang Fatwa di Jakarta, Selasa 25 Desember 2012.

Amin, Ma'ruf. Fatwa dan Perubahan Sosail, dalam Fatwa-fatwa Masalah Pernikahan dan Keluarga, Jakarta: Elsas, 2008.

Amin, Ma'ruf. Pengantar Komisi Fatwa dalam Fatwa Munas VII Majelis Ulama Indonesia, Jakarta: Majelis Ulama Indonesia, 2005.

Andiko, Toha. "Ijtihad M. Quraish Shihab Dalam Merespon Problematika Hukum Islam Kontemporer", Jurnal Manhaj, Vol. 12 No.1, Januari-Juni 2012.
Andiko, Toha. Pemberdayaan Qawa'id Fiqhiyyah Dalam Penyelesaian Masalah-Masalah Fikih Siyasah Modern, Al-'Adalah, Vol. 12, no.1 (2014).

Arkoum, Mohammed. Rethinking Islam: Common Questions Uncommon Answers, Translated and Edited by Robert D. Lee, Colorado and Oxford: Westview Press, 1994.

Aziz, Abdul (ed.). Gerakan Kontemporer Islam di Indonesia, Jakarta: Pustaka Firdaus, 1989.

Azra, Harun Nasution dan Azyumardi. Perkembangan Modern dalam Islam, Jakarta: Obor, 1985.

Departemen Pendidikan Nasional, Kamus Besar Bahasa Indonesia, Jakarta: Balai Pustaka, 2003.

Direktorat Jenderal Bimbingan Masyarakat Islam dan Penyelenggaraan Haji, Himpunan Fatwa Majelis Ulama Indonesia, Jakarta: Departemen Agama RI, 2003.

Fayumî, Al-Misbah al-Munîr Fî Gharib al-Syarh al-Kabîr li al-Rafi'i, Kairo: Mathba'ah alAmiriyah, 1965.

Federspiel, Howard M. Persatuan Islam: Pembaharuan Islam Indonesia AbadXX, terj. Yudian W. Asmin dan Affandi Mukhtar, Yogyakarta: Gadjah Mada University Press, 1996.

Hamidah,Tutik. "Pemikiran Feminis Muslim Indonesia", Disertasi UIN Syarif Hidayatullah Jakarta, 2009.

Hamsin, Muhammad Khaeruddin, Perkawinan Beda Agama dalam Tinjauan Syariah dan Hukum Positif (Menyoal Pasal 2 ayat (1) UU No. 1 Th. 1974), Makalah tidak dipublikasikan.

Hasil Keputusan Rapat Komisi Fatwa, tanggal 23 Muharram 1422/12 April 2001.

Ismail, Iffatul Umniati. "Telaah Kritis Metodologi Istinbath MUI (Studi Kasus Fatwa Tentang Golput)", Media Syariah, Vol. XIII, No 1, Januari-Juni 2011.

Jaib, Sa'di Abu. Qamus al-Fiqhi Lughotan wa Istilahan, Damascus: Dar al-Fikr, 1988.

Jurjani, Ali bin Muhammad Abu Hasan al-. AlTảrifât, Beirut: Dar al-Kutub al-ilmiyah, t.th. Khâzin, 'Ala al-Din 'Ali bin Muhammad bin 
Ibrahim al-Baghdadî al-. Tafsîr al-Khâzin, Beirut: Dar al-Kutub al-Ilmiyah, $1415 \mathrm{H}$, Jilid II.

Lubis, Ridwan dan Syahminan. Perspektif Pembaharuan Pemikiran Islam, Medan: Pustaka Widyasarana, 2004.

Ma'luf, Louis. Al-Munjid fi al-Lughah wa alA lâm, Beirut: Dar al-Masyriq, 1976, Jilid. I.

Mahfudh, M.A.Sahal dkk. Himpunan Keputusan Musyawarah Nasional VII Majelis Ulama Indonesia, Jakarta: Majelis Ulama Indonesia, 2005.

Mishri, Muhammad bin Mukram bin Manzhûr al-Ifriqi al-. Lisân al-Arab, Beirut: Dar alShadr, t.th, Jilid 15.

Mudzhar, Mohammad Atho. Fatwa-Fatwa Majelis Ulama Indonesia: Sebuah Studi tentang Pemikiran Hukum Islam di Indonesia (1975-1988), Jakarta: INIS, 1993.

Muhdlor, Atabik Ali, dan Zuhdi. Qamus AlAshri, Arabi Indunesi, Krapyak: Multi Karya Gratifika, 2003.

Munawwir, Ahmad Warson. Kamus al-Munawwir Arab Indonesia Terlengkap, Yogyakarta: Pustaka Progresif, 1994.

Mushtofa, Ibrahim dkk. Müjam al-Wasîth, T.t: Dar al-Da'wah, t.th., Jilid 2.

Pedoman dan Prosedur Penetapan Fatwa Majelis Ulama, dalam Ma'ruf Amin, Himpunan Fatwa Majelis Ulama Indonesia Sejak 1975, Jakarta: Erlangga, 2011.

Qadiry, Abdullah Ahmad. Nikah Beda Agama Menurut Islam. Terjemahan dari Syaihu Asnawi, Yogyakarta: Media Wacana, 2012, Cet. I.

Qardlawî,Yusuf al-. Al-Fatwa Bain Al-Indlibath Wa Al-Tasayyub, Mesir: Dar al-Qalam, t.th.

Qasimi, Muhammad al-. Mabâhis At-Takwîl, Damascus: Dar al-Fikr, 2011, Jilid XVII.

Rais, Isnawati. Hukum Perkawinan dalam Islam. Jakarta: Balitbang, 2006, Cet. I.

Razi, Abu Abdullah Muhammad bin Umar bin Al-Hasan al-Taimi al-. Mafâtih al-Ghaib, Beirut: Dar Ihya Turats al-'Arabi, t.th, Jilid I.
Ridho, Muhammad Rasyid bin Ali. Tafsîr alManâr, Mesir: Al-Hai'ah al-Mishriyah al'Ammah Lil Kitab, 1990, Jilid II, VI, VI.

Rusli,Nasrun. Konsep Ijtihad al-Syaukani, Jakarta: PT. Logos Wacana Ilmu, 1999.

Sabiq, Sayyid. al-Figh al-Sunnah, Kairo: Dâr alFikr, 1997, jilid II.

Saeed, Islamic Thought An Introduction, London and New York: Routledge, 2006.

Sayis, Muhammad 'Ali al-. Tafsir Ayat al-Ahkâm, Mesir: Maktabah al-Ashriyah, 2002.

Sekretariat Majelis Ulama Indonesia Pusat, Himpunan Keputusan Musyawarah Majelis Ulama Indonesia VII, Jakarta: Majelis Ulama Indonesia, 2010.

Shabuni, 'Alial-. Tafsir ayatal-Ahkam, Damascus: Dar al-Fikr, t.th, Jilid I

Shihab, M.Quraish. Tafsir al-Misbah Pesan Kesan dan Keserasian Al-Qur'an, Bandung: Muzan, 2000, Vol. I.

Shihab, Quraish. Wawasan Al-Quran Tafsir Maudhu'i atas Pelbagai Persoalan Umat, Bandung: Mizan, 1996.

Shin'ani, 'Abd al-Razzaq bin Hamma al-. Tafsir al-Qur'an, Riyadh: Maktabah al-Rusyd, $1410 \mathrm{H}$, Jilid II.

Sholeh, Asrarun Niam. Fatwa-fatwa masalah Pernikahan dan Keluarga, Jakarta: Elsas, 2008.

Syarifuddin, Amir. Usûl al-Fiqh, Ciputat: Logos Wacana Ilmu, 2001, Jilid II.

Syathibi, Al-Muwafaqat fi Ushul al-Syariat, Beirut: Dar al-Rasyid al-Haditsah, t.th, Juz 3.

Usman, Iskandar. Istihsan dan Pembaharuan Hukum Islam, Jakarta: Rajawali dan LSIK, 1998.

Voll, John O. "Renewal and Reform in Islamic History, Tajdid and Islah,” dalam John L. Esposito (ed.), Voices of Resurgence Islam, Oxford: Oxford University Press, 1983.

Wâhidî, Abu al-Hasan 'Ali ibn Ahmad al-. Asbâb Nuzûl al-Qurân, Kairo: t.p., 1968.

Zuhaili,Wahbah al-. Usûl al-Fiqh al-Islâmi, Damaskus: Dar al-Fikr, 1426 H/2005 M, Juz 2. 